\title{
Determination of Lead and Zinc in urine in Saudi population
}

\author{
Hatem Abdel Moniem Abmed, Muhammad Naeem Janjua, \\ Jawaher Soliuman Mosafar Albediea \\ Department of Forensic Chemistry, College of Forensic Sciences, Naif Arab University for Security Sciences, \\ Riyadh, Saudi Arabia.
}

\begin{abstract}
Cigarettes contain over 4000 chemicals including heave metals like lead and zinc; over 20 are probably carcinogenic and over 60 are mutagenic. Approximately 11\% of the lead in the cigarette enters the smoke, and half of that is believed to enter the smoker's lungs. Zinc is also present in cigarettes (average $24 \mu \mathrm{g} / \mathrm{gm})$ and about $70 \%$ of it is transferred to the smoke. Prolonged exposure to lead and zinc is associated with multiple health hazards and may also lead to various neurological and metabolic disorders. In the present study, Lead and Zinc were determined in urine samples of smokers $(n=30)$, passive smokers $(n=30)$ and nonsmokers $(n=17)$ from different districts of Riyadh, Saudi Arabia. Analysis was performed using Graphite Furnace Atomic Absorption Spectrophotometry (GFAAS) for lead and Flame Atomic Absorption Spectrophotometry (FAAS) for zinc. The mean urine lead and zinc concentration in smokers was higher than non-smokers, while concentration of lead and zinc in urine samples of passive smokers was more or equal to smokers. Our results have shown that available concentrations of lead and zinc are higher in smokers and passive smoker's urine than non-smokers, and a correlation exists between lead and zinc concentrations and the period of smoking.
\end{abstract}

Key words: GFAAS, FAAS, Lead, Zinc and Urine.

\section{Introduction}

Heavy metals enter biological fluids throw many sources, food, cigarette smoking, by intake of contaminated liquids and also by inhaling fuel smokes. In recent years, tobacco smoking has become one of the major sources of intake of heavy metals. It has been shown that environmental tobacco smoke (ETS) also plays a significant role in increasing the health hazards associated with tobacco smoke [1]. According to the World Health Organization (WHO) report published in 2009, about 50,000 non-smoker Americans pay with their lives due to ETS, and on a worldwide scale, this figure soars to 600,000. Seven-hundred million children suffer because of ETS exposure at home due to a smoking parent or guardian [2]. It has also been established that smoking is an important factor in the production of carcinoma of lungs, [3,4]. It has been reported that levels of these heavy metals in urine are indicators of human exposure [4]. Heavy metals have ability to accumulate in tissues of humane body and their overall potential to be toxic even at relatively minor levels of exposure [5]. Heavy metal toxicity is an uncommon but clinically significant medical condition which can result in various illnesses, diseases or even death if not recognized in time and treated appropriately. Acute Cd ingestion in high doses irritates the gastric epithelium resulting in nausea, vomiting, abdominal cramps and pains [6,7]. Zinc is essential for growth, spermatogenesis, skeletal development, skin protection, brain development and clinical improvement in atherosclerosis, [1,8,9]. Exposure to abnormally high levels of $\mathrm{Zn}$ can result in various adverse health effects. Acute ingestion of high levels of $\mathrm{Zn}$ can cause stomach cramps, nausea, and vomiting [10]. Ingesting high levels of zinc for several months may cause anemia, damage the pancreas, and decrease levels of high-density lipoprotein cholesterol [11]. Interactions between $\mathrm{Zn}$ and other metals such as $\mathrm{Cd}, \mathrm{Ca}, \mathrm{Cu}$, and $\mathrm{Fe}$ occur in the process of its absorption and utilization. Cd uptake into the walls of the duodenum, jejunum and ileum is depressed at high concentrations of $\mathrm{Zn} \mathrm{[10].} \mathrm{Zn}$ stands out for having some opposite effects to other metals, and as such the protective effects of $\mathrm{Zn}$ against $\mathrm{Cd}$ toxicity have been reported, Selenium Poisoning on line [12]. Toxicity of lead has also been well documented. One of the molecular mechanisms for toxicity of lead is oxidative stress [1]. By the effect of lead, reactive oxygen species (ROS) levels increase via elevated intracellular $\mathrm{Ca} 2+[3]$.

The present study attempts to discuss the extent to which a relationship exists between smoking habit and the concentrations of lead and zinc in urine.

\section{Materials And Methods}

Twenty-four hours urine samples were collected from fully consented volunteers from different districts of Riyadh city in sterilized urinary bags. The samples collection cut across different age groups and professions. Total numbers of samples were 77, (30 from male smokers, 30 from passive smokers and 17 from non-smokers). Prior to the urine collection, sterilized urinary bags were soaked in $5 \% \mathrm{HNO} 3$ for overnight, 
rinsed with distilled water and $0.1 \mathrm{M} \mathrm{HCI}$ before collecting urine samples. After the collection, samples were filtered through $0.45 \mu \mathrm{m}$ syringe filters, $10 \mu \mathrm{l}$ of conc. $\mathrm{HNO}_{3}$ per $1 \mathrm{ml}$ of urine sample was added and the treated urine samples were stored at $-20^{\circ} \mathrm{C}$ till further procedure.

Five milliliter of the urine sample was digested by the method described by Simeonove et al., [13]. Concentration of lead was determined with Agilent Spectrometer GTA 120 (Agilent Technologies, Inc., USA), while zinc was determined by Agilent FAA Spectrometer FS 240

Technologies, Inc., USA).

\section{Preparation of working standard of Lead for GFAAS}

Stock standard solution of $\mathrm{Pb}(1000 \mathrm{ppm})$ was purchased from Panreac Quimica SA (Barcelona Spain). $1 \%$ solution of extra pure $\mathrm{NH}_{4} \mathrm{H}_{2} \mathrm{PO}_{4}$ (Loba Chemie Pvt. Ltd. India) was prepared in deionized distilled water and used as modifier.

Single working standard of $\mathrm{Pb}(200 \mathrm{ppb})$ was prepared by diluting the stock standard of $\mathrm{Pb}(1000 \mathrm{ppm})$ with 0.5 N HNO3.

Atomic absorption spectrometer was programmed to make auto dilution of 40,100, 160 and $200 \mathrm{ppb}$ from the single working standard ( $200 \mathrm{ppb})$ to achieve the linear calibration curve as well as take equal volumes (1:1) of bulk and working standard. The standard and samples were measured with 3 replicates (3 runs) to achieve appropriate mean values.

\section{Preparation of working standard of zinc for Agilent FAAS}

Stock standard solution of zinc (1000 ppm) was purchased from Fisher Scientific Ltd. (UK).

\section{Working Standards of zinc}

Working standards of Zn were prepared by diluting the stock standard solution of $\mathrm{Zn}(1000 \mathrm{ppm})$ to yield $0.1,0.6$ and $1.2 \mathrm{mg} / \mathrm{l}$ of $\mathrm{Zn}$, respectively. Working

Standards were aspirated manually to FAAS to obtain the linear calibration curve.

Table 1: Concentrations of lead used in the calibration curve for smokers, non-smokers and passive smokers.

\begin{tabular}{cllllllll}
\hline Metal & Concentration $\boldsymbol{\mu g} / \mathbf{l}$ & Run 1 & Run 2 & Run 3 & Mean & SD & & RSDrep \% \\
& & & & & & & & \\
\hline \multirow{2}{*}{ Lead } & 40 & 0.3481 & 0.3730 & 0.3660 & 0.3660 & 0.013 & 3.544 \\
& 100 & 0.7295 & 0.7540 & 0.7540 & 0.7530 & 0.014 & 1.860 \\
& 160 & 1.0381 & 1.0419 & 1.0419 & 1.0419 & 0.002 & 0.211 \\
& 200 & 1.2054 & 1.1990 & 1.1970 & 1.1970 & 0.004 & 0.366 \\
& & & & & RSDrep \% & 1.495 \\
\hline
\end{tabular}

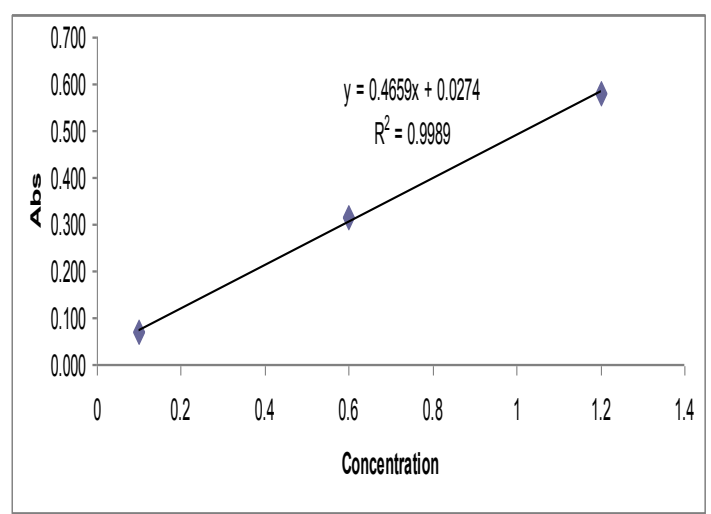

Figure (1). Calibration curve for lead: concentrations (40,100, 160 and $200 \mathrm{ug} / \mathrm{l})$; area under the curve and linear atomic absorption device.

Table 2: Concentrations of zinc used in the calibration curve for smokers, non-smokers and passive smokers.

\begin{tabular}{lllllllll}
\hline Metal & Concentration $\boldsymbol{\mu g} / \mathbf{l}$ & Run 1 & Run 2 & Run 3 & Mean & SD & & RSDrep \% \\
& & & & & & & \\
\hline \multirow{3}{*}{ Zinc } & 0.1 & 0.069 & 0.068 & 0.069 & 0.069 & 0.001 & 1.457 \\
& 0.6 & 0.320 & 0.310 & 0.320 & 0.317 & 0.006 & 1.823 \\
& 1.2 & 0.585 & 0.575 & 0.586 & 0.582 & 0.006 & 1.058 \\
& & & & & & & RSDrep \% & 1.058 \\
\hline
\end{tabular}




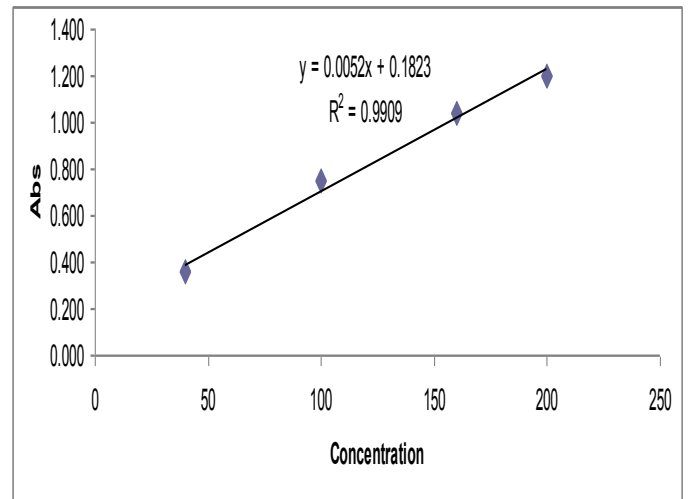

Figure (2). Calibration curve for zinc: concentrations $(0.1,0.6,1.2 \mathrm{mg} / \mathrm{L})$; concentration; area under the curve and linear atomic absorption device.

Table 3. Accuracy of the analytical method based on measuring the concentrations for zinc at absorption pinnacles Petkraria the three measurements for each concentration.

\begin{tabular}{|c|c|c|c|c|c|c|}
\hline \multirow[t]{2}{*}{ Parameters } & \multicolumn{2}{|c|}{ Results } & \multicolumn{2}{|c|}{ Accepted values } & \multicolumn{2}{|c|}{ Accepted } \\
\hline & Lead & Zinc & Lead & Zinc & Lead & Zinc \\
\hline Line & & & Linear & Linear & Accepted & Accepted \\
\hline $\mathbf{R}^{2}$ & 0.9909 & 0.999 & More than 0.95 & More than 0.95 & Accepted & Accepted \\
\hline Range & & & $40-200 \mu \mathrm{g} / 1$ & $0.1-1.2 \mathrm{mg} / 1$ & & \\
\hline RSDrep \% & 1.46 & 2.546 & Less than $15 \%$ & Less than $15 \%$ & Accepted & Accepted \\
\hline Mean & 99.348 & 94.993 & & 94.993 & & \\
\hline SD & 10.398 & 8.615 & & 8.615 & & \\
\hline $\begin{array}{l}\text { RSD \% } \\
\text { (Accuracy) }\end{array}$ & 10.466 & 9.068 & Less than $15 \%$ & 9.068 & Accepted & Accepted \\
\hline
\end{tabular}

Table 4. Limit of detection and limit of quantitation for lead and zinc

\begin{tabular}{ccc}
\hline Element & LOD & LOQ \\
\hline Lead & $11.52 \mu \mathrm{g} / \mathrm{l}$ & $34.93 \mu \mathrm{g} / \mathrm{l}$ \\
Zinc & $0.01 \mathrm{mg} / \mathrm{l}$ & $0.03 \mathrm{mg} / \mathrm{l}$ \\
\hline
\end{tabular}

\section{Results and Discussions}

Table 5: levels of metals ( $\mathrm{Pb}$ and $\mathrm{Zn}$ ) of selected smokers in urine samples.

\begin{tabular}{|c|c|c|c|}
\hline $\begin{array}{l}\text { No. } \\
\text { sample }\end{array}$ & $\begin{array}{l}\text { Year of } \\
\text { smoking }\end{array}$ & $\begin{array}{ll}\text { Conc. } & \text { of } \\
\text { Lead } \mu \mathrm{g} / \mathrm{l}\end{array}$ & $\begin{array}{l}\text { Conc. of } \\
\text { zinc mg/l }\end{array}$ \\
\hline 1 & 9 & 103.35 & 0.63 \\
\hline 2 & 5 & 141.92 & 0.72 \\
\hline 3 & 12 & 112.33 & 0.63 \\
\hline 4 & 3 & 101.55 & 0.72 \\
\hline 5 & 10 & 111.92 & 0.56 \\
\hline 6 & 3 & 99.13 & 0.57 \\
\hline 7 & 7 & 112.33 & 0.75 \\
\hline 8 & 15 & 123.01 & 0.71 \\
\hline 9 & 3 & 132.00 & 0.64 \\
\hline 10 & 15 & 185.54 & 0.72 \\
\hline 11 & 1 & 171.97 & 0.58 \\
\hline 12 & 4 & 115.83 & 0.79 \\
\hline 13 & 9 & 132.43 & 0.86 \\
\hline 14 & 9 & 180.53 & 1.03 \\
\hline 15 & 2 & 117.80 & 0.81 \\
\hline 16 & 10 & 118.57 & 0.77 \\
\hline 17 & 3 & 142.47 & 0.69 \\
\hline 18 & 3 & 146.24 & 0.78 \\
\hline 19 & 7 & 133.62 & 0.45 \\
\hline 20 & 2 & 111.34 & 0.43 \\
\hline 21 & 10 & 130.84 & 0.42 \\
\hline 22 & 6 & 91.03 & 0.46 \\
\hline 23 & 2 & 153.96 & 0.73 \\
\hline 24 & 10 & 152.37 & 0.69 \\
\hline 25 & 15 & 117.80 & 0.55 \\
\hline 26 & 17 & 179.74 & 0.51 \\
\hline 27 & 7 & 162.68 & 0.63 \\
\hline
\end{tabular}




\begin{tabular}{|l|l|l|l|}
\hline 28 & 5 & 154.75 & 0.61 \\
\hline 29 & 5 & 117.36 & 0.53 \\
\hline 30 & 4 & 140.14 & 0.69 \\
\hline
\end{tabular}

Table 6: levels of metals ( $\mathrm{Pb}$ and $\mathrm{Zn})$ of selected passive smokers in urine samples.

D: Detection

\begin{tabular}{|l|c|c|}
\hline No. sample & $\begin{array}{l}\text { Conc. } \\
\text { Lead } \mathbf{\mu g} / \mathbf{l}\end{array}$ & Conc. of zinc $\mathbf{~ g g / l}$ \\
\hline 1 & 146.99 & 0.71 \\
\hline 2 & 191.60 & 0.51 \\
\hline 3 & 94.01 & 0.52 \\
\hline 4 & 80.28 & 0.40 \\
\hline 5 & 11.70 & 0.38 \\
\hline 6 & 99.56 & 0.71 \\
\hline 7 & 99.11 & 0.61 \\
\hline 8 & 39.69 & 0.45 \\
\hline 9 & 56.81 & 0.46 \\
\hline 10 & 80.97 & 0.30 \\
\hline 11 & 96.06 & 0.45 \\
\hline 12 & $\mathrm{D}$ & 0.28 \\
\hline 13 & 83.29 & 0.23 \\
\hline 14 & $\mathrm{ND}$ & 0.34 \\
\hline 15 & 69.38 & 0.27 \\
\hline 16 & 62.94 & 0.27 \\
\hline 17 & 86.27 & 0.43 \\
\hline 18 & 59.54 & 00.35 \\
\hline 19 & 88.25 & 0.34 \\
\hline 20 & 159.25 & 0.30 \\
\hline 21 & 106.72 & 0.43 \\
\hline 22 & 89.06 & 0.28 \\
\hline 23 & 92.02 & 0.25 \\
\hline 24 & $\mathrm{D}$ & 0.20 \\
\hline 25 & 103.96 & 0.29 \\
\hline 26 & $\mathrm{ND}$ & 0.46 \\
\hline 27 & $\mathrm{D}$ & 0.29 \\
\hline 28 & $\mathrm{D}$ & 0.48 \\
\hline 29 & 47.22 & 0.45 \\
\hline 30 & 47.13 & 0.30 \\
\hline & & \\
\hline
\end{tabular}

ND: Not detected

Table 7: levels of metals ( $\mathrm{Pb}$ and $\mathrm{Zn})$ of selected non- smokers in urine samples.

\begin{tabular}{|c|c|c|}
\hline No. sample & $\begin{array}{l}\text { Conc. of } \\
\text { Lead } \mu \mathrm{g} / \mathrm{l}\end{array}$ & $\begin{array}{l}\text { Conc. of } \\
\text { zinc mg/l }\end{array}$ \\
\hline 1 & 40.66 & 0.30 \\
\hline 2 & 80.24 & 0.36 \\
\hline 3 & 88.60 & 0.26 \\
\hline 4 & 84.70 & 0.16 \\
\hline 5 & 91.72 & 0.10 \\
\hline 6 & 68.49 & 0.33 \\
\hline 7 & 91.38 & 0.22 \\
\hline 8 & 100.98 & 0.26 \\
\hline 9 & 89.73 & 0.19 \\
\hline 10 & ND & 0.12 \\
\hline 11 & $\mathrm{D}$ & 0.10 \\
\hline 12 & 78.41 & 0.16 \\
\hline 13 & 72.38 & 0.21 \\
\hline 14 & 111.90 & 0.16 \\
\hline 15 & 94.44 & 0.25 \\
\hline 16 & 71.00 & 1.3 \\
\hline 17 & 93.19 & 0.99 \\
\hline
\end{tabular}

Heavy metals are present in the human body, and some of them are important while others are not. The ratio of their concentration in the body can be determined in blood and urine, but blood and urine Don't give the accurate ratio present in humane body [3]. In the present study, we have attempted to determine the mean urine concentration of lead and zinc in smokers and passive smokers and compared with urine samples taken from non-smoker. Also we have made comparison with the international maximum allowed limits, and have tried to study the correlation between concentration of these elements and the duration of smoking. Our results have shown that the concentration of lead and zinc was higher in smokers and passive smokers than the non-smokers, Tables $(5,6,7)$. 
Our results agree with Simeonove et al. (2011) [13], who proved in his studying, that the concentration of lead and zinc is high for smoker than non-smoker. Our studying clear that, smoking may be the reason for increasing concentration of heavy metals in smoker urine (Table 5), this agree with Bamgobose, O. et al.(2007) [14], who found that the concentration of lead, zinc and other heavy metals is high in different tobacco products. Through this study, it is proved that, the concentration level of lead in smoker is between $91.03-185.54 \mu \mathrm{g} / \mathrm{l}$, which is higher than the international maximum allowed limits $(0.01-2.14 \mu \mathrm{g} / \mathrm{l})$, while the concentration level of zinc in smoker is between $(0.42-1.03 \mathrm{mg} / \mathrm{l})$ which is higher than the international maximum allowed limits $(0.44-$ $0.499 \mathrm{mg} / \mathrm{l})$, (Table 5). Our results agree with Verma, S.et al (2010) [15], who proved that the concentration of lead in urine $(0.02-4.8 \mu \mathrm{g} / \mathrm{l})$, and the level of zinc $(0.049-0.968 \mathrm{mg} / \mathrm{l})$. table $(7)$ shows that, the concentration of lead in non-smoker is between $(10.94-111.90 \mu \mathrm{g} / \mathrm{l})$ which is more than international maximum allowed limits, perhaps this is due to large number of nonsmokers people exposure to automobile exhaust and contamination of food and water with heavy metals, this results agree with Peter Heitland et al.(2006) [16], who determined some heavy metals $(\mathrm{Pb})$ for workers in the production of steel using GFAAS and digestion with nitric and hydrochloric acids and compare these results with non-workers, the results proved that, concentration of lead for worker more than the concentration of non-workers in this field. Other study revealed that, Saudi Arabia from 1980 to 1990 was used gasoline content on a high percentage of lead up to $0.42 \mathrm{~g} /$ liter. In addition to other sources of exposure such as herbal medicines and various traditional treatments such as henna and incense, [17]. While, table (7) shows that the concentration level of zinc in non-smoker $(0.1-0.36 \mathrm{mg} / \mathrm{l})$, which lie in international maximum allowed limits.

This study clear that, concentration of zinc and lead in urine passive smoker more than non-smoker, this may be due to, passive smoker inhale the pure components of tobacco, through burring the tobacco, this agree with Al-Saleh,I. et al., (1994b) [18], who found higher values of urinary nicotine and cotinine in passive smokers compared to non-smokers in the present study. This study revealed that, the level of lead and zinc directly proportional with the duration of smoke (Table 6), but there are some levels of lead and zinc are high in short duration smoke compared with levels of lead and zinc with high duration smoke, this may due to the difference in the quantity of smoke intake (number of cigarettes delay) and kind of tobacco [19].

\section{References}

[1] Richard, R., Bake and Christopher J. Proctor, (1990), (The origin and Properties of Environmental Tobacco Smoke), Environ. Int., 16: 231-235.

[2] World Health Organization (WHO), (1990). Women and Tobacco. Int. J. Health Dev., 11: 3-13.

[3] Shaham, J., A. Meltzer, R. Ashkenazi and J. Ribak, (1996). "Biological Monitoring of exposure to Cadmium, ahuman Carcinogen, as a result of active and passive smoking". J. Occup. Environ. Med., 38: 1220-1228.

[4] Daube, H., G. Scherer, K. Riedel, T. Ruppert, A.R. Tricker, P. Rosenbaum and F. Adikofer, (1997). "DNA adducts in human placenta in relation to tobacco smoke exposure and plasma antioxidant status". J. cancer. Res. Clin. Oncol., 123: 141-151.

[5] Buchancova, J., M. Knizkova, D. Hyllova, M. Vrlik, D. Mesko, G. Klimentova and E. Galikova. (1994). "content of the selected trace elements (Al, As, $\mathrm{Cd}, \mathrm{Cu}, \mathrm{Fe}, \mathrm{Hg}, \mathrm{Mn}, \mathrm{Ni}, \mathrm{Pb}, \mathrm{Zn}$ ) in blood, urine and air of blood donors without occupational exposure these metals. Cent. Eur. J. Public Health, 2:82-87.

[6] Hu, H: Human Health and heavy metals exposure. In: life support: The environment and human health, McCally, M. (ed), MIT press, (2002), $1-13$.

[7] ATSDR: Toxicological profile for cadmium. U.S. Department of Health and Human Services, Public Health Service, Agency for Toxic Substances and Disease Registry, Atlanta, Georgia, (1999).

[8] Drebler, J., Schulz, K., (2002). "lethal manganese cadmium intoxication". A case report. Arch Toxicol., 76: 449 - 451.

[9] Underwood, EJ: “Trace Elements in Human and Animal Nutrition”, 4th Ed., Academic Press, New York, (1977): 1 - 421.

[10] ATSDR: Toxicological Profile for Zinc. U.S. Department of Health and Human Services, Public Health Service, Agency for Toxic Substances and Disease Registry, Atlanta, Georgia, (2005).

[11] Leblond, VS and Hontela, A, (1999). "Effects of in vitro exposure to cadmium, mercury zinc and 1-(2-chlorophenyl)-1-(4chlorophenyl)-2,2- dichloroethane on steroidogenesis by dispersed inter- renal cells rainbow trout (Oncorhynchus mykiss)". Toxicol.Appl. Pharmacol., 157: 16.

[12] Selenium Poisoning, on-line, http://www.ansci.cornell.edu/plants/locoweed/se2.htm

[13] Simeonove, et al., (2011). "Environmental heavy metals pollution and effect on child metal development: Risk Assessment and prevention strategies", DOI, 10.1007/978-94-007-5253-0-8.

[14] Bamgbose,O.; Opeolu, B. O and Bamgbose, J. T., (2007). "Levels of cadmium, lead and zinc in urine of randomly selected smokers and non-smokers residents of Abeokuta City", Nigeria Research Journal of Applied Sciences 2 (2): $192-197$.

[15] Verma,S.; Yadav,S.; Singh, I., (2010). "Trace metal concentration in different Indian tobacco products and related health implications". Food and Chemical Toxicology: 48 ,2291-2297.

[16] Peter Heitland and Helmut D. Ko"ster, (2006). "Biomonitoring of 30 trace elements in urine of children and adults by ICP-MS", Clinica Chimica Acta 365 (2006) 310 - 318.

[17] Horng, Ching-Jyi.; Tsai, Jin-Lian.; Horng, Ping-Hua.; Lin, Shih-Ching.; Lin, Shinine-Ren.and Tzeng, Cherng-Chyi., (2002). "Determination of urinary lead, cadmium and nickel in steel production workers". Talanta, $56,1109-1115$.

[18] Al-Saleh, I., et al., (1994b). "A Characterization of The Blood Lead Concentration in Saudi Arabian Children". Ann. Clin. Biochem. 31:469-472.

[19] Digambar Behera, Rajan Uppal \& Sidharath Majumdar, (2003). "Urinary levels of nicotine \& cotinine in tobacco users", Indian J Med Res 118, September, pp 129-133. 